\title{
TEMA Y EFECTOS: SEMÁNTICA Y PRAGMÁTICA EN EL COMENTARIO DE TEXTOS POÉTICOS
}

\author{
ÁNGEL LUIS LUJÁN ATIENZA \\ Instituto de la Lengua Española. C.S.I.C.
}

\begin{abstract}
Se me perdonará que arranque con un recuerdo personal. Cuando allá en los lejanos tiempos de la escuela se nos mandaba hacer el comentario de un poema, era rara la vez que acertábamos con el tema. Describir la estructura métrica, incluso descubrir las figuras nos resultaba relativamente fácil a los pocos que teníamos algún interés en aquella tarea crítica primeriza: bastaba con poseer un poco de memoria, entender los ejemplos y haber practicado mínimamente. Sin embargo, el tema siempre se nos escurría. Nuestra perplejidad, además, llegaba a extremos mayúsculos cuando aparecían como candidatos temas lo suficientemente dispares como para dar la impresión de que no hablábamos del mismo poema. A veces incluso ni siquiera las personas mayores se ponían de acuerdo sobre la cuestión temática. El caso es que habitualmente acabábamos con la mente confusa, y cada vez más vacilantes a la hora de emprender el siguiente comentario. Y esa era otra, porque la determinación del tema constaba generalmente como uno de las primeros puntos en nuestros infantiles esquemas de comentario. Debido a situación tan privilegiada, entendíamos que con la asignación de tema se nos pedía algo que de manera escueta comprendiera el significado global del poema (incluso en ocasiones se definía en esos términos o parecidos). Pero nosotros, sin conocer todavía a Tolstoy ni a Ana Karenina, intuíamos que lo que quería decir el texto era lo que decía. Otras veces se nos presentaba el tema como aquello de lo que hablaba el texto, pero aquí surgía el problema de que ciertos poemas hablaban de diversas cosas a la vez. Otros poemas, por su parte, si eran abarcados con una etiqueta demasiado extensa, no decían absolutamente nada. Si apuntábamos que el tema de un poema era el amor, bajo esa descripción cabían millones de poemas de la literatura universal, y lo mismo pasaba con la muerte; así que por ese camino no íbamos a ningún sitio. Si descendíamos a detalles más concretos y escribíamos, por ejemplo, que un poema trataba de los ojos de la amada, ahí también se presentaba toda una legión de candidatos para ocupar plaza. Cabía el soneto de Garcilaso que comienza
\end{abstract}


«De aquella vista pura y ecelente», «Tu pupila es azul» de Bécquer, e incluso el soneto a una dama bizca de Quevedo, así que nos quedábamos de nuevo en ayunas. La gran tentación era la de la paráfrasis, que teníamos, como bien se sabe, completamente prohibida.

Me reencontré con esta perplejidad muchos años después, cuando escribía mi manual sobre comentario de textos poéticos, y me di cuenta de que no se trataba sólo de una estupefacción privada y personal sino que era compartida más o menos por todos los que habían tratado sobre el asunto. Cada uno a su manera (y yo lo hice también) miraba de bandearse como mejor podía con esa espinosa cuestión: qué es un tema. Espero que el repaso que emprendo de ciertas obras teóricas y, sobre todo, de creación contribuya a arrojar sobre ella un poco más de luz.

\section{EL TEMA DEL TEMA}

Las dificultades de que me acabo de hacer eco tienen un fiel reflejo en todos los manuales de comentario de textos que conozco. En primer lugar, los autores en conjunto parecen estar de acuerdo en que en el apartado «tema» se debe especificar la clave de contenido que da unidad al significado del poema ${ }^{1}$. Es lo que Carlos Reis define como «sentido nuclear del poema» ${ }^{2}$, y en lo que abunda el autor de un reciente manual: «De aquí en adelante, a esta idea global del significado del texto la denominaremos el tema» ${ }^{3}$. Se trata de la visión tradicional que aparece en el clásico manual de Tomachevski: «El tema (aquello de lo cual se habla) está constituido por la unidad de significados de los diversos elementos de la obra» ${ }^{4}$. Conviene preguntarse, ante afirmaciones de este tipo, si una entidad exclusivamente de contenido, esto es semántica, puede cumplir la función de dar unidad al sentido al poema, o incluso agotarlo en su integridad ${ }^{5}$.

I Véase, por ejemplo, LÁzaro CARreter y Correa CALderón, Cómo se comenta un texto literario, Madrid, Cátedra, 1990, 28. ${ }^{a}$ ed., p. 31; Isabel Paraíso, El comentario de textos poéticos, Gijón/Valladolid, Júcar/Aceña, 1988, p. 22.

2 Carlos ReIs, Comentario de textos. Fundamentos teóricos y análisis literario, Salamanca, ediciones Colegio de España, 1995, p. 113.

3 Manuel CAMARERo, Introducción al comentario de textos, Madrid, Castalia, 1998, p. 15.

4 Boris Tomachevski, Teoría de la literatura, Madrid, Akal, 1982, p. 179.

5 En el volumen que dedica la revista Poétique $(64,1985)$ a la cuestión temática bajo el título «Du thème en littérature», aunque encontramos artículos que defienden un acercamiento más de tipo pragmático a la noción de tema, sin embargo sigue dominando la consideración del tema como unidad de sentido y aplicado al análisis de géneros narrativos, fundamentalmente. Cito unas palabras significativas de uno de los colaboradores, Shlomith Rimmon-Kenan: «Dans cette perspective, le thème - ou tout au moins le thème dominant - est le signifié global, homologue du dénominateur structural 
Lo más cercano a una exposición globalizadora del contenido del poema es la paráfrasis, que no consiste más que en el resumen puramente conceptual o semántico del poema. Y es por ello por lo que repetidamente es desaconsejada por autores y profesores. Lo cual es prueba clara de que ningún elemento de contenido agota la unidad de sentido del poema.

Es el mismo problema que encontramos si definimos el tema como aquello de lo que el poema habla, pues nos seguimos moviendo en el nivel de contenido exclusivamente. Aquí el problema aparece bajo el aspecto de la excesiva generalización. Carlos Reis, por ejemplo, nos dice que el tema del poema es una idea o un sentimiento universal: el amor, la muerte... una abstracción, en definitiva ${ }^{6}$. Esto sirve quizá para inscribir el poema en una serie: entre los poemas de amor, de muerte, etc..., útil para clasificaciones genéricas o para realizar antologías, pero raramente una idea tan general nos hablará del poema en particular que tenemos entre manos. Y si tratamos de ser más concretos siempre habrá otros muchos poemas que traten el mismo tema, y cuanto más intentemos huir de esa generalidad más cerca estaremos de la paráfrasis. En consecuencia, decir que el tema es aquello de lo que habla el poema desemboca igualmente en la paráfrasis.

Para salvar estos escollos se introdujo el concepto de motivo ${ }^{7}$. Por motivo se entiende aquello a través de lo que el poeta dice lo que dice, lo cual nos libera de la trampa anterior que escondía el hecho de considerar sinónimos contenido y unidad de significado. En esta línea está también la acuñación de Eliot del «correlato objetivo», pensado en principio para explicar las intervenciones de personajes dramáticos y no para la literatura en su conjunto ${ }^{8}$. Pero esta opción tiene sus desventajas. La primera y más obvia es que muchas veces el poeta dice lo que dice directamente sin in-

commun qui émerge sinon du tout, du moins de la plupart des aspects formels de l'oeuvre littéraire. Bien que cette notion me semble s'appliquer aussi bien à la poésie qu'à la fiction narrative, je tirerai mes exemples de cette dernière» (p. 404). La misma incidencia en lo narrativo se detecta en el número monográfico de Communications $(47,1988)$ titulado: «Variations sur le thème».

6 Carlos REIS, Comentario de textos. Metodología y diccionario de términos literarios, Salamanca, Almar, 1979, p. 115.

7 KAYSER, W., Interpretación y análisis de la obra literaria, Madrid, Gredos, 1976, $4^{\circ}$ ed., pp. 71-81; Segre, C., Principios de análisis del texto literario, Barcelona, Crítica, 1985, p. 349; GuIllén, C., Entre lo uno y lo diverso, Barcelona, Crítica, 1985, pp. 248 y ss. Hay que distinguir entre el motivo así entendido y el motivo tal como lo usan los formalistas rusos, en tanto que unidad narrativa. Véase TOMACHEVSKI, op. cit., pp. 185-186: «El tema de una parte indivisible de la obra se llama motivo. En resumen, cada frase tiene su motivo. Pero es preciso advertir que el término 'motivo' empleado por la poética histórica en el estudio comparativo de las tramas 'errantes' (...), es sustancialmente distinto de la aceptación aquí adoptada, aunque, en general se define como motivo una unidad temática que se repite en diversas obras».

8 ELIOT, T. S., «Hamlet», en Selected Essays, Faber and Faber, London, 1972, 3. edición, p. 145. 
terponer correlatos ni imágenes, como muchas de las rimas más populares de Bécquer. Por otra parte, hay poemas en que los motivos se multiplican sin estar subordinados a una idea central. ¿Habría entonces muchos temas o uno solo? Piénsese, por ejemplo, en el poema de García Lorca «Tu infancia en Mentón» o «Galope muerto» de Pablo Neruda. Se trata de poemas basados en la técnica de yuxtaposición de imágenes. Son ejemplo también el poema de Octavio Paz, «Piedra solar», y algunos de Aleixandre.

No obstante, la distinción entre significado y motivo esconde una intuición sobre la manera de superar ese desajuste surgido del intento de hacer del tema el núcleo de sentido del poema. El poema quiere decir algo y para ello utiliza distintos medios (sintácticos, prosódicos, etc.) entre los que se encuentran las unidades de contenido, llamémosles temas o motivos. Así, la unidad de lo que el poema pretende decir, el espacio en el que convergen todos los elementos poemáticos, no puede ser de orden semántico sino pragmático. Bajo este punto de vista se pregunta no lo que el poema quiere decir (que ya lo dice siendo tal poema) sino el efecto que pretende provocar en el lector. Como todo tipo de enunciación, un poema antes de hablar sobre algo habla para algo. Lo que propongo, en fin, es la vuelta a una lectura retórica del texto lírico; retórica en su sentido más puro: arte de creación de un discurso eficaz dirigido a un fin ${ }^{9}$. Y en lo que nos concierne, lo que se pide en los comentarios de texto cuando se habla de tema (confusamente, según se ha mostrado) tiene que ver más con la fase de intellectio de la antigua retórica que con la inventio, es decir, más con idear las estrategias del decir con respecto a un objetivo determinado que con la elección concreta de materiales de contenido. Frente a un discurso expositivo de tipo «conferencia científica», en que el significado y las intenciones del hablante se agotarían en los límites del tema, en la poesía el tema es un pretexto (uno más) para provocar una reacción en el público, un efecto de orden estético.

Han sido sobre todo los poetas, y no los teóricos, los más receptivos a este problema. Encontramos esta reflexión en Jaime Gil de Biedma: «Los temas de sus poemas (de V. Aleixandre) - no el asunto o argumento, sino el efecto que intentan producir: para un poeta, ése es el verdadero tema de un poema- me gustan muy poco. Y sin embargo, siempre que se los oigo

9 Sobre el carácter retórico de la literatura ha insistido Miguel Ángel Garrido en un doble sentido: «los procedimientos que se ponen en práctica para hacer un discurso atrayente con una finalidad estética son los mismos, al menos en parte, que se llevan a efecto para hacer un discurso atrayente con una intención persuasiva», y «sin olvidar que todo texto literario entraña algo de persuasivo, pues todo autor nos quiere atraer más o menos conscientemente a su punto de vista: entre retórica y poética tampoco existe solución de continuidad» (Nueva introducción a la teoría de la literatura, Madrid, Síntesis, 2000, p. 13). Véase una propuesta afín en Georges MoliniÉ, Sémiostylistique. L'effet de l'art, Paris, PUF, 1998, pp. 96-98. 
leer, me sobrecogen» ${ }^{10}$. Y creo que es el blanco al que apunta José Ángel Valente cuando distingue entre tema, objeto y forma del poema: «El objeto del poema es la zona de realidad, poéticamente conocida, que el poema revela. El tema es el enunciado genérico de esa realidad, que aun así enunciada puede seguir estando encubierta. El tema no determina la forma; en cambio, entre ésta y el objeto hay un condicionamiento dialéctico. El tema es por sí solo poéticamente inerte (...). La capacidad de revelación poética de la realidad tampoco está condicionada en definitiva por la personal actitud del artista respecto al posible tema de la obra. La actitud es en buena medida parte de la disposición temática y, como tal, no determina a la forma. El objeto, sí. El tema es intencional; se busca, se propone o se impone. El objeto es sobreintencional, se encuentra, pues es la zona de realidad que la palabra inventa, es decir, halla» ${ }^{11}$. Mientras que el objeto, en la particular poética de Valente, es lo que podíamos considerar el efecto final producido por todo poema: la revelación de una realidad que no existe fuera del poema, el tema es como el asiento conceptual que permite que esa revelación siga teniendo relación con nuestro mundo terreno, que no sea del todo evanescente. La forma final del poema viene dada por el objeto y no por el tema.

En definitiva, los elementos de contenido, junto con la forma de expresión, constituyen momentos del texto que están al servicio de la intención pragmática, la única capaz de dar unidad al sentido del poema. Considérese, por ejemplo, que en obras en que el título nos indica sin lugar a dudas de qué habla el poema no siempre es eso lo que resume el núcleo del significado. La oda «al aire» de Pablo Neruda habla evidentemente del aire, pero su intención significativa es de protesta: denuncia la apropiación y comercialización injustas de bienes naturales como el agua y la luz.

\section{EFECTOS E INTENCIONES}

Hablar de efectos en literatura no está muy bien visto, principalmente porque la existencia de un efecto supone alguien que pretenda provocarlo, esto es, un sujeto de intenciones conscientes que hasta hace unas décadas se llamaba autor ${ }^{12}$. Con la muerte del autor, por tanto, nos hemos quedado

10 GIL DE BIEDMA, Jaime, Retrato del artista en 1956, Barcelona, RBA editores, 1993, p. 196.

1 José Ángel VALENTE, «Literatura e ideología. Un ejemplo de Bertolt Brecht», en Las palabras de la tribu, Barcelona, Tusquets, 1994, pp. 38-39.

${ }_{12}$ Son de obligada mención en el contexto de esta discusión los trabajos clásicos de W. K. WIMSATT, Jr., "The Intentional Fallacy» and «The Affective Fallacy», recogidos ambos en The Verbal Icon. Studies in the Meaning of Poetry, New York, The Noonday Press, 1958. Como se verá, defiendo aquí un concepto de intención y de efecto (no necesariamente emocional) distintos de los criticados en estos dos artículos. 
también sin efectos estéticos. Los poemas no están dichos para provocar nada en nadie. Según esto, tampoco es comprensible por qué la gente se empeña en leer, a no ser que se deba a algún tipo de perversión genética.

En contraste con esta situación propongo la siguiente definición, que cabe dentro de la teoría de una lectura retórica del poema: un efecto es el correlato de una intención inscrita como tal en el poema. He tratado de este asunto en otros dos artículos ${ }^{13}$, pero aquí voy a centrarme principalmente en mostrar cómo la determinación de los efectos poemáticos puede sustituir a la problemática categoría de tema, cuando se entiende éste como unificador del sentido del poema, según se ha dicho. Se trata de sentar las bases teóricas de lo que después sería aplicable a la metodología concreta del comentario de textos.

Para entender qué es un efecto en poesía no hace falta ir muy lejos, basta parangonar el poema con cualquier otro tipo de discurso. Cuando hablamos o escribimos pretendemos crear cierto efecto en el oyente y este efecto depende no sólo de la intención del hablante en bruto sino también de las constricciones interpretativas que impone el género y la situación en que los interlocutores se encuentran. Todo el mundo ha experimentado la dificultad, el embarazo incluso, que supone la intención de producir un verdadero efecto (de sinceridad y sentimiento) en géneros tan codificados como el pésame. Por lo mismo, en poesía el efecto no puede ser confundido con la intención del autor. El efecto será la intención del autor (en cuanto «hacedor» de discurso y no persona privada) inscrita en el texto; pero el texto no es un medio transparente, como la crítica no se ha cansado de repetir: el texto pertenece a un género y depende de una situación. Además, en literatura son fundamentales las constricciones que impone el canal, ya que la escritura implica un grado muy elevado de autonomía y de enajenación de la comunicación. El tener en cuenta todos estos factores es lo que diferencia el ingenuo vertido de un sentimiento en verso por parte de un adolescente de la expresión verdaderamente poética de ese mismo sentimiento por parte de un autor hábil. Como afirma Umberto Eco: «Ante todo, por cooperación textual no debe entenderse la actualización de las intenciones del sujeto empírico de la enunciación, sino de las intenciones que el enunciado contiene virtualmente» ${ }^{14}$. El concepto de efecto estaría a medio camino entre las categorías de acto ilocutivo y efecto perlocutivo. El efecto perlocutivo, es decir, el realmente ocasionado en el receptor es incontrolable y nunca puede estar inscrito como tal en el texto; sin embargo, todo acto ilocutivo (éste sí inscrito en el texto como tal) prevé por el

\footnotetext{
13 «Elementos para el estudio de la enunciación lírica. Una tipología de los sonetos de Garcilaso de la Vega» (en curso de publicación), y «Modos de conciencia y efectos poéticos en lírica», en Diálogo de la Lengua (en curso de publicación).

14 ECO, Umberto, Lector in fabula, Barcelona, Lumen, 1981, p. 90.
} 
mero hecho de existir una serie de posibles efectos perlocutivos. Si yo amenazo a alguien, en condiciones normales, esperaré que esa persona se asuste o que a su vez me amenace a mí, y no que me dé la enhorabuena o que me pase la sal.

Un ejemplo de cómo las intenciones explícitas del autor quedan desmentidas por las convenciones literarias nos lo muestra Jaime Gil de Biedma al comentar un soneto de Guillén: «Mundo continuo». Según comunicación personal a Biedma, Guillén pretendía con este poema «describir 'la interrupción discordante que se produce a veces en el amor más continuo. Amor como suma cotidiana. Esa interrupción está representada en el primer terceto. Sin embargo, a pesar de la crisis, permanece fluyendo el río amoroso y su realidad continúa su marcha acostumbrada hacia su plenitud, en el mar'». Sin embargo, como muestra Biedma en el análisis subsiguiente, esta intención se ve contrarrestada en el poema por dos causas, primero porque la situación amorosa aparece simplemente aludida y por la cita final de Jorge Manrique (los ríos que van a dar al mar) que nos lleva a pensar en la muerte más que en la continuidad fluida del amor: «Sucede, a pesar de la cita de Shakespeare que encabeza la composición y a pesar del verso primero, que uno no cae en la cuenta de que la relación amorosa constituye el ámbito situacional del poema, sino que inmediatamente la trasciende (...). Segunda, y más importante. El esquema de representación definido por el siguiente conjunto: el río que sin acción de retorno va dando su realidad al mar, posee en sí mismo, gracias a la vitalidad manriqueña - «nuestras vidas son los ríos...»- una fuerza tal de polarización que, ayudado por su posición privilegiada a final de poema, acaba por desalojar al otro esquema, propiamente guilleniano. En la sensibilidad del lector se opera, pues, algo muy parecido a un cortocircuito, y la conjunción del esquema manriqueño con una serie de términos conllevadores de valores positivos proporciona al conflicto una solución bien diferente de aquella querida por el poeta: parece como si la certeza de la muerte, al despojar de todo sentido a nuestro mundo, se erigiese en la única auténtica realidad $\mathrm{y}$, también, en el único consuelo» ${ }^{15}$.

Aquí vemos cómo las intenciones explícitas no resultan apropiadamente incluidas en el poema y su lectura presenta dificultades. El mismo Gil de Biedma nos ofrece un ejemplo en que las intenciones personales sí aparecen reflejadas en el texto. En un pasaje de su diario da cuenta de la impresión que causa en él el relato que le hace María Zambrano (están en Roma) de la multitud reunida en la plaza cantando la Internacional: «Habló de nuestra guerra, del éxodo final, de su emoción al escuchar el otro día la Internacional cantada por una multitud en la Piazza del Popolo, con

15 Jaime GIL DE BIEDMA, El pie de la letra. Ensayos completos, Barcelona, Crítica, 1994, pp. 112-114. 
tal viveza, con tanta intensidad que me sentí dignificado, exaltado a una altura significativa, purificado de todo deseo trivial» ${ }^{16}$. Este momento queda recogido en el poema «Piazza del Popolo». El poeta, en lugar de expresar directamente su reacción ante el relato, que podía desvirtuar el propio sentimiento, elige desaparecer como enunciador, y construye el poema como un monólogo de María Zambrano, de manera que a la vez que su emoción queda, implícitamente, inscrita en el texto permite que llegue sin mediación al público para provocar la ilusión de un contacto directo con tal emoción. Incluso la canción cantada, prudentemente silenciada por problemas de censura, puede leerse (a buen entendedor) en el poema: «Oh sí, cantábamos todos / otra vez, qué movimiento, / qué revolución de soles / en el alma!». Este ejemplo nos es útil, además, para señalar que el autor elige la imagen propia que proyecta en el poema y esa imagen es la que gobierna la retórica de los efectos. En este caso la decisión del autor consiste precisamente en borrarse de la enunciación del poema como medio más eficaz para producir el efecto. Por otra parte, el lector tiene que tener en cuenta el grado de manipulación que supone la reproducción en verso escrito de una intervención conversacional que fue, supuestamente, oral y en prosa.

Tampoco debemos confundir el efecto con el acto de habla pretendido por el hablante en el poema (que no siempre es representación directa del autor, según se acaba de ver). El efecto es el que el poeta pretende crear en el lector a través de su texto. Por eso, cuando tenemos poemas en segunda persona hay que distinguir entre dos actos ilocutivos: el que se dirige a la persona interna al poema y el que se dirige al público lector, que es el genuinamente estético: el primero no existe más que para provocar el segundo. Fijémonos, para ilustrar este punto, en la distinta intención de dos sonetos petrarquistas, dirigidos ambos en segunda persona a la amada. Me refiero al soneto $\mathrm{V}$ de Garcilaso, «Escrito está en mi alma vuestro gesto», y al soneto de Góngora que comienza «De pura honestidad templo sagrado». En ambos el poeta muestra su adoración por la amada pero de modo bien distinto y con efectos completamente opuestos. En el soneto de Garcilaso el hablante del poema se dirige a la amada con una galante declaración amorosa: "Yo no nací sino para quereros», pero ese no es el efecto estético que pretende conseguir. Lo sería en el caso de que el sentimiento fuera verdadero y lo leyera la persona a la que se dirige; pero estamos ante un poema que leemos nosotros, lectores ya del siglo XXI, y el efecto (o mejor: abanico de efectos posibles) que nos debe causar está inscrito en el poema como tal y no fuera de él. En primer lugar, aunque el poema evidentemente se ha escrito, puede estar pensado como una comunicación tanto escrita como oral. Parece, por lógica interna, que se

16 Retrato del artista..., p. 122. 
trata de un enunciado que se pretende escrito, pues habla de escritura y de que el poeta se guarda de la amada (lo que hace improbable la ilusión de un intercambio in praesentia); no obstante nada impide que pueda ser dicho o pensado por el poeta a sí mismo, ya que a pesar de la artificialidad que supone la forma «soneto» el lenguaje es directo, la sintaxis sencilla y el vocabulario ordinario. Éstas son marcas de que el escrito puede reclamar el carácter de enuncido oral ${ }^{17}$. Por tanto, hay una indeterminación que el lector tiene que tener en cuenta. El poema es evidentemente escrito: si lo pensamos como escrito no hay mayor problema; pero si lo consideramos como dicho o pensado el poeta nos está invitando a un juego: a que imaginemos al propio poeta o hablante diciendo o pensando eso, es decir, que ideemos una imagen, que desplacemos y apartemos nuestra imaginación de la situación (real) del poeta escribiendo con su pluma en la mano y devanándose quizá los sesos. Como el autor no ha inscrito de manera explícita la situación y la ha dejado a elección del lector, éste está autorizado a crear la situación que quiera. En cualquier caso, la sensación que se nos da es de sinceridad. Entiéndase sinceridad dentro de las convenciones petrarquistas: no hay ningún elemento irónico, ni excesiva formalización, e incluso la vacilación entre el carácter oral o escrito del poema hace que el lector sienta más cerca, casi inmediata la voz que se le propone.

En conclusión, habría que preguntarse iqué pretende alguien que se dirige a la amada, aparentemente de modo sincero, ante un público general? Es de justicia reconocer que en estos casos siempre hay algo, si no de teatral, al menos de ceremonioso: el público asiste a una declaración amorosa que se finje no estar pensada para que la presencie. En principio, el lector se podría limitar a su condición de mero espectador: juzgar lo acertado o no del acto de habla que se intenta. Pero la poesía no reclama nuestra atención como meros espectadores, sino más bien nuestra participación como implicados en la comunicación real que es el poema. Así, el efecto que se pretende será aproximadamente el mismo que pretende alguien que se declara en público con protestas de sinceridad. En realidad, repito, se trata siempre de una gama de efectos, ya que el efecto concreto en cada lector es absolutamente privado. En primer lugar, se puede provocar una identificación del lector con el poeta, y así éste se erigiría en modelo del buen amar; e imaginemos cuántas veces no ha modelado la literatura nuestra manera de amar. Si el lector adopta el papel del destinatario (amada), puede desear que alguna vez se le dirijan tales requiebros, o sentir que efectivamente se le están dirigiendo. Incluso desde una posición más abarcante, el lector se puede sentir enternecido por la situación, reconocer en ella la

17 Para una exposición de las posibles relaciones entre escritura y oralidad ver Daniel CASSANY, Describir el escribir. Cómo se aprende a escribir, Barcelona, Paidós, 1991, pp. $44-48$. 
verdadera esencia del amor, etc. Lo más probable es que el efecto glọbal esté compuesto por una mezcla de todos estos sentimientos. Además, se pueden matizar los distintos efectos dependiendo de la imagen que nos hayamos hecho de la situación de enunciación: si pensamos al poeta escribiendo realmente, tenderemos a ver el poema como una declaración literaria y nos podemos sentir jueces ante todo; si imaginamos al poeta cara a cara con la amada entonces podemos sentirnos principalmente espectadores y podemos aceptar más fácilmente cualquiera de los dos papeles: el del poeta o el de la amada; si imaginamos al poeta en un soliloquio tenderemos a identificarnos más con él sentimentalmente porque imaginativamente nos hemos trasladado a su mismo imaginar (recordemos que el poeta está en realidad escribiendo el poema). Es decir, el lector reacciona ante una declaración pública que se le presenta como tal. No se trata, en ningún caso, de pretender sentir lo mismo que el poeta, pues como bien dice Miguel Ángel Garrido: «Por de pronto, las emociones suscitadas por la literatura no son las mismas de la vida real: no existe garantía alguna de que revivan la emoción originaria que desencadenó en el artista la inspiración de la obra, tampoco de que la obra reproduzca en el receptor las mismas emociones originarias. La literatura no entrega emociones, sino percepción de emociones» ${ }^{18}$.

El soneto de Góngora, en que se representa la misma demostración de devoción y con carácter de declaración pública, es sin embargo muy distinto, como aparece ya a la simple intuición; diferencia de la que no sabría dar cuenta un análisis puramente contenidístico. En primer lugar, el poema no se pretende dicho: la artificiosidad de la forma métrica va unida a la artificiosidad del lenguaje y el vocabulario, premeditadamente literario. Si el poema de Garcilaso podía leerse en alto con cierta sensación de naturalidad no ocurre así con el de Góngora. Y no obstante el poeta pretende que se trata de una comunicación oral: «oye». Lo que hace Góngora con esta contradicción es poner de manifiesto la literatura como juego: si en Garcilaso quedaba ambiguo el estatus del soneto como dicho o escrito, aquí el juego se pone en primer plano como tal. Además, el objeto directo de «oye» es a todas luces una hipérbole: «tus himnos canta y tus virtudes reza». Aquí, por tanto, tenemos desechada desde el principio toda pretensión de sinceridad.

En segundo lugar se sitúa la cuestión de la identidad del hablante. Si en Garcilaso no había ninguna determinación individualizadora más que la del amante de la tradición petrarquista, que aparecía como escritor pero sin hacer alarde de ello, aquí, por la artificiosidad formal que se despliega ante nuestros ojos el hablante aparece en primer lugar como poeta más que como amante, es alguien cuya primera misión es forjar el «monumen-

\footnotetext{
18 Nueva introducción a la teoría de la literatura, p. 28.
} 
to» que leemos. Además, es un enunciador que abusa de la hipérbole, por lo que no estamos seguros de hasta qué punto su intención es irónica. Pero hay otro dato: en el poema se compara a la amada con un templo y el hablante se presenta como fiel o incluso como sacerdote. $\mathrm{Y}$ el caso es que sabemos que el autor es efectivamente un clérigo y este saber es inseparable de nuestra lectura del poema. Se inscribe en el texto, con ello, un elemento provocador, al que responde el padre Pineda ${ }^{19}$. Góngora entra imaginativamente en el poema no como el clérigo cristiano que es, sino como un adorador págano de su «ídolo». Nótese la incongruencia entre describir en este contexto a la amada como «templo» y después dirigirse a ella como «ídolo». Hay una discontinuidad y una contradicción tematizada entre cristianismo (templo y clérigo Góngora) y paganismo (ídolo y clérigo en el poema), con base todo ello en la afirmación paulina de que nuestros cuerpos son templos del Espíritu' Santo ${ }^{20}$.

En cuanto al efecto global, aunque estamos ante una declaración como en el caso anterior, aquí el poeta no pretende que el lector se identifique con ninguno de los hablantes en el poema, entre otras cosas porque ninguno se presenta como real (son hiperbolizaciones imaginativas). La única posible identificación con el hablante es como poeta, caso en que invita a la aemulatio. Ya no asistimos a esa vacilación garcilasiana entre escritor y amante, que pretende un equilibrio entre ambos papeles; en Góngora el escritor ha desbancado al amante. Se nos pide, de hecho, la admiración por la fábrica lingüística erigida por el poeta, que admitamos el juego de la literatura como tal y que pensemos en la conciliación o disparidad entre posturas paganas y cristianas con respecto a los códigos poéticos de la época. El lector no debe reaccionar aquí, al contrario que en el soneto de Garcilaso, ante una declaración amorosa pública, sino ante el juego poético que toma como excusa esa misma declaración.

Creo que se desprende claramente de los ejemplos contrastantes la serie de puntos a los que debemos atender a la hora de determinar los efectos inscritos en el poema, efectos parciales que cooperan en la creación de un efecto global que da unidad al sentido del poema y que sustituye en esa función al concepto de tema.

\section{UNA LECCIÓN DANTESCA}

Los problemas que estoy tratando recibieron atención ya en los albores de la creación lírica europea y así aparecen recogidos en una de las pri-

19 Góngora, Luis de, Sonetos completos, ed. de Biruté Ciplijauskaité, Madrid, Castalia, 1985, p. 118.

20 Corintios, I,VI,19. 
meras reflexiones sobre el hecho de escribir poemas. Me refiero a La vita nuova de Dante. Una cala en algunos de sus pasajes puede servirnos de guía para mostrar cómo la unidad de sentido del poema es, desde su inicio, de orden pragmático y que el poema está pensado en principio para provocar algo en el lector antes que para hablar sobre algo ${ }^{21}$.

En primer lugar está la cuestión, a la que ya he aludido, del carácter del poeta como personaje público, no como sujeto de intenciones privadas. Este carácter público del oficio de poeta queda patente en la manera en que el aspirante ingresa en la «cofradía» literaria. Como si se tratara de un gremio, Dante debe demostrar su buen hacer (en el que ya se había ejercitado, según confesión propia) para ser sancionado como miembro por los más viejos en el oficio. Para ello escribe un soneto en que se dirige a los trovadores consagrados proponiéndoles una especie de acertijo, que es el sentido de un sueño o visión que ha tenido (pp. 7-9). Este soneto tiene una doble función. Dirigido a los demás poetas, reclama una respuesta (que varios de ellos efectivamente dieron), respuesta que supone una sanción y una aceptación dentro de su círculo. Además, repárese en que el poema se plantea como reto: Dante da muestras de su maestría en el terreno propio de los poetas, en el desarrollo de la imaginación y el ingenio. Pero, por otra parte, el poema, como todo poema, está dirigido a un público general. En este nivel, el público debe juzgar la pericia de Dante en el oficio y cómo es merecedor de entrar en el gremio. Como si se tratara de un concurso público, Dante debe ser sancionado por los poetas, y esto tiene que ser puesto en conocimiento general de la ciudadanía.

A partir de este momento, el poeta no es un individuo privado sino una función dentro de la estructura social de la ciudad. Tiene, en primer lugar, limitados sus temas al del amor: " $Y$ esto es contrario a los que riman sobre otra materia que la amorosa, ya que tal manera de hablar fue ideada desde un principio para tratar de amor» (p. 77). En consecuencia, el poeta tiene el deber de mostrarse como enamorado (aunque Dante confiesa que su enamoramiento era real), y es interrogado por los demás sobre la identidad de su amada. El poeta también recibe encargos como si de cualquier artesano se tratara: «Luego que esta canción comenzara a divulgarse entre las gentes, como la oyese un amigo mío, el deseo le hizo rogarme que le dijera qué es Amor, demostrando por las palabras que había oído una confianza en mí mayor de la que merecía» (51); "Y luego que llegó para conversar conmigo, rogóme que le escribiese alguna cosa sobre una dama que había muerto» (93); «Después, dos nobles damas mandaron a pedirme que les enviase algunas de mis composiciones rimadas» (115).

Dante nos ofrece unos cuantos ejemplos de cómo las intenciones pri-

21 Utilizaré la edición bilingüe de Julio Martínez Mesanza: Dante ALIGHIERI, La vida nueva, Madrid, Siruela, 1985. 
vadas deben ceder ante las intenciones puramente poéticas. En un momento de su biografía se ve obligado a desviar la atención del público de su verdadero objeto amoroso (para preservar el secreto) usando como pantalla o excusa a otra dama de la que finge estar enamorado. La dama en cuestión abandona un día la ciudad y entonces Dante se ve en la obligación de cantar una canción triste, pues es lo que todo el mundo espera de él como poeta-amante: «Y pensando que si yo no hablaba dolorosamente de su partida, las gentes advertirían antes mi simulación, me propuse lamentarme de ello en un soneto» (13). El soneto empieza: «O voi, che per la via d'Amor passate», y la gente lo recibe como lamentación por la ausencia de la dama que piensan ser la amada del poeta. Las intenciones privadas no cuentan para la interpretación del texto, ésta depende de lo que hay en él escrito y de lo que se espera del poeta. Ahora bien, Dante nos dice cuáles eran sus intenciones privadas y señala los versos donde están reflejadas textualmente, es decir, los versos que dentro del poema se refieren directamente a su verdadera amada: «Amor, no por mi bondad escasa, sino por su nobleza, vida me consintió tan dulce y suave, que a menudo escuchaba tras de mí: 'Dios, ¿por qué privilegio tiene éste su corazón así de alegre?'». Este fragmento sólo puede desligarse del resto del poema una vez que Dante expone públicamente la posibilidad de hacerlo, pero mientras tanto (y aún después) estamos autorizados a leer el poema como una unidad de sentido en que se llora la ausencia de la dama y se compara con el estado de felicidad anterior. Así, pues, la única intención auténtica es la inscrita en el texto. Dante nos enseña cómo usar una parte de su texto, pero no necesitamos hacerle caso para que el poema tenga sentido como unidad.

Otro ejemplo del mismo tipo ocurre en el poema «Morte villana, di pietà nemica» (17). Al dividir este poema nos dice Dante: «en la cuarta [parte] me dirijo a una persona indeterminada aunque para mi entendimiento sea determinada». El verso en cuestión es «Quien no merezca salvación, no espere jamás conseguir su compañía», y debe entenderse como dirigido no a la dama cuya muerte se lamenta en el poema sino a la amada, que acompañó en vida a la joven muerta. Aquí tenemos un problema de pragmática más concreto que en el caso anterior: el de la referencia. La referencia consiste en indicar a qué individuo extratextual se refiere una expresión lingüística y por tanto depende no sólo de la voluntad del emisor, sino que ésta tiene que ser reconocida por el receptor para que resulte apropiada la acción de referir. Ahora bien, el poeta como persona de carne y hueso no es el que refiere, sino el poeta en tanto que presente en el texto. Si aquí la referencia se deja indeterminada, como dice Dante, la referencia es indeterminada, independientemente de lo que pase realmente por su cabeza.

Un caso fronterizo lo constituye la canción que comienza «Quantunque 
volte, lasso! mi rimembra» (97). El poema consta de dos estancias que según Dante están pensadas como procedentes de dos voces distintas, la suya propia como amante, y la del hermano de la amada, que le ha encargado el poema: «Por lo cual, antes de darle este soneto hice dos estancias de una canción, una realmente para él, y otra para mí, aunque una y otra, para quien no las mira sutilmente, parecen dirigidas a la misma persona». A continuación Dante nos da la pista lingüística para saber que la voz es distinta en cada estancia: «pero quien sutilmente las mira advierte con facilidad que hablan personas distintas, ya que una no llama a aquélla su dama, y la otra sí, como claramente aparece» (95). Este es, a todas luces, un caso dudoso y nos ayuda también a pensar en cuánta sutilidad hay en la lectura de poesía: el más pequeño detalle lingüístico es signo de un elemento que transforma el poema completamente. Es, además, una de las primeras veces que se alude a la deconstrucción en la crítica literaria. Desde luego que estamos autorizados a leer el poema como si se tratara del producto de una sola voz, pero después de conocer el matiz introducido por Dante podemos leerlo como incluyendo la posibilidad de discernir dos voces en él. Así, pues, en el poema no sólo está inscrita la intención del poeta sino incluso la intención de ambigüedad, de una doble lectura, o voluntad de producir una «obra abierta» en palabras de Eco.

Una importante consecuencia de estas declaraciones dantescas es que modifican la imagen del poeta dentro de la tradición para dar arranque a una tradición nueva. El poeta ya no puede seguir siendo visto como alguien que textualmente dice lo que dice sino como alguien que puede haber incluido sentidos «ocultos», pero permitidos en cualquier caso por el texto. Es decir, nos autoriza a desgajar fragmentos del texto rompiendo su unidad si parecen apuntar a otro sentido, descubrir referencias desviadas, etc. Lo cual indica, a su vez, que la imagen del poeta se va forjando con cada práctica poética nueva. Cada nuevo poeta particular modifica de alguna manera la imagen pública del poeta en general.

Otro aspecto ilustrado en esta reflexión de Dante sobre su propia poesía es el de la intención que anima todos sus poemas y la poesía en general: la alabanza de la amada. Las declaraciones en este sentido son explícitas y abundan en la obra: «hice para ella [dama-pantalla] ciertas cosillas en rima, que no es mi intención transcribir aquí, sino en cuanto traten de la gentilísima Beatriz; por ello las dejaré todas a un lado, salvo algunas de ellas que escribiré porque va en alabanza suya» (11); «Por lo que me propuse tomar siempre como materia de lo que escribiese aquello que fuera en alabanza de mi gentilísima» (45); «por lo que yo, pensando en esto y queriendo proseguir el librito de su alabanza, me propuse escribir...» (79), etc. En principio esta es una decisión y un asunto totalmente privados, que afectan como mucho al amante. ¿Qué sentido tiene entonces el hacer pública la alabanza de la amada? La propuesta de Dante es sencilla. Para él 
Beatriz y el amor que siente por ella son fuente de perfeccionamiento espiritual y en último extremo de salvación (piénsese en la etimología de su nombre). El libro abunda en ello. Veamos, por dar una muestra, cómo describe Dante el efecto que tiene en él el saludo de la amada: «Digo que cuando ella aparecía en cualquier parte, por la esperanza del maravilloso saludo ningún enemigo me quedaba; por el contrario, venía a mí una llama de caridad, que me hacía perdonar a todo aquel que me hubiese ofendido» (23). Beatriz efectúa en el poeta la aparición de la mayor virtud cristiana: la Caridad. El amor de Beatriz no es sólo el amor terreno sino que lleva unido a él el amor divino que garantiza la salvación. Ante tan extraordinario hecho el poeta no puede hacer otra cosa que intentar que el público en general reconozca y comparta con él el poder salvífico que atribuye a su amada, y para eso usa como instrumento la poesía, a través de la cual los lectores deben realizar una elevación espiritual pareja a la suya. La alabanza de la dama debe llegar a todos para que obre el nacimiento del amor: «... palabras en las que mostrase cómo por ella despierta este Amor, y cómo no sólo despierta allí donde duerme, sino cómo ella, obrando admirablemente, lo hace nacer también donde no está en potencia» (53).

En principio esta proclamación va dirigida a la ciudad donde habita el poeta (y Beatriz también), allí donde su función poética es reconocida. Sin embargo, al final del libro, Dante decide saltar las barreras del público cortesano de su villa al que se había dirigido hasta ahora, y descubre el poder universal de su poesía (al fin y al cabo un mensaje de salvación lleva implícito en sí una intención de universalidad). El poeta puede expresar esa idea de perfección espiritual a cualquier hombre. La ocasión son unos peregrinos que pasan por su ciudad, atentos a sus cosas y por completo ajenos al drama de la muerte de Beatriz. Esto le hace a Dante caer en la cuenta de que si Beatriz tiene un poder de salvación universal éste se debe extender incluso a quienes no la conocen (por ser extranjeros) y ahí es donde entra en juego la poesía. La poesía es una manera de hacer saber, de colocar a todos los lectores en el camino del mejoramiento espiritual y la salvación a través de la alabanza de la amada: «La ciudad ha perdido a su Beatriz; y las palabras que pueden decirse de ella tienen el poder de hacer llorar a los demás» (115). De ahí que la poesía de Dante siga teniendo vigencia hoy día (y cada uno puede entender «salvación»a su gusto). Y de ahí también el nacimiento de la Divina Comedia, obra donde la alabanza de la amada está en el centro de toda una reflexión sobre la vida y el destino humanos: «Así, si quiere Aquel por quien todas las cosas viven que mi vida dure algunos años, espero decir de ella lo que nunca fue dicho de ninguna» (119). Con ello Dante logra salir del círculo de poeta de corte y crea la imagen del poeta maestro universal a la altura de los clásicos de la antigüedad. Esta imagen es a la que tendrán que res- 
ponder los poetas que le siguen; es el legado que recibe Petrarca y que ejerce a su modo.

Con esta excursión por la Vita nuova de Dante espero haber iluminado algunas cuestiones de orden metodológico, que son aplicables a la didáctica del comentario de textos. En primer lugar, debemos empezar por buscar en el poema no aquello de lo que trata, sino aquello que pretende conseguir, la intención tal y como viene inscrita en el texto, teniendo en cuenta la tradición poética, pues la pragmática del poema remite a un tiempo histórico, o mejor dicho, a dos: el de la producción y el de la recepción. Debemos pensar que el poema está escrito para que nosotros lo leamos, y que quien a nosotros se dirige no es una persona privada sino una entidad de orden público, cuya imagen e intenciones son las que aparecen inscritas en el texto. Debe quedar claro, además, que el efecto no es el sentido del poema (que, por otra parte, siendo todo no es nada) sino el eje en torno al cual se unifica ese sentido y al que se subordinan todos los elementos semánticos, formales y estructurales del poema, de manera que podamos reconocer a éste como el poema concreto que leemos. Incluso los poemas que se presentan como carentes de unidad de sentido pretenden provocar un efecto unificador: el de la ausencia de unidad. 